4. Management of enterprises of the tourist sphere with the use of modern information technologies. URL: https://web.znu.edu.ua/herald/issues/2011/eco_2011_1/2011_1/148-153.pdf (accessed 30 August 2021) [in Ukrainian]

5. The State Fixed Service named the number of travel companies in Ukraine. URL: https://zruchno.travel/News/New/4922?lang=ua (accessed 27 August 2021) [in Ukrainian]

6. The current state of the tourist market of Ukraine. URL: http://www.economy.nayka.com.ua/pdf/10_2018/59.pdf (accessed 27 August 2021) [in Ukrainian]

7. Innovative and IT technologies in tourism. URL: http://dspace.nuft.edu.ua/jspui/bitstream/123456789/25887/1/22.PDF (accessed 27 August 2021) [in Ukrainian]

8. Concepts of innovative development of enterprises in the field of tourism. URL: https://knute.edu.ua/file/ODc0Mw==/53ec8a30e688165ab46cb806c8831614.pdf (accessed 27 August 2021) [in Ukrainian] 9. Analysis of innovative development of domestic tourism enterprises in the Ukrainian market. URL: https://tourlib.net/statti_ukr/kravchenko22.htm (accessed 27 August 2021) [in Ukrainian]

10. Tour operator «Join Up». URL: https://joinup.ua/ (accessed 29 August 2021)

11. Tour operator «Anex Tour». URL: http://anextour.com.ua/ (accessed 29 August 2021)

12. Tour operator «TPG». URL: https://www.tpg.ua/ (accessed 29 August 2021)

Дата подання публікації 30.08.2021 p.

УДК 658:339.138

Морохова В.О., к.е.н., професор

Morokhova V., Candidate of Economic Sciences, Professor https://orcid.org/0000-0001-9246-7633

Бойко О.В., к.е.н., доцент

Boyko O., Candidate of Economic Sciences, Associate Professor https://orcid.org/0000-0001-7153-5617

Лорві І.Ф., к.е.н., доцент

Lorvi I., Candidate of Economic Sciences, Associate Professor https://orcid.org/0000-0001-6713-5338

\title{
МАРКЕТИНГОВІ ТЕХНОЛОГІЇ ФОРМУВАННЯ КОНКУРЕНТНИХ ПЕРЕВАГ ПІДПРИЕМСТВ
}

\author{
Луцьккий національний технічний університет
}

В статті розглянуто питання використання маркетингових технологій 3 метою формування конкурентних переваг. Систематизовано дослідження зарубіжних і вітчизняних науковців стосовно джерел конкурентних переваг. Узагальнено вимоги, яким мають відповідати конкурентні переваги та наведено систематизований перелік характеристик, через які виявляється сутність конкурентних переваг. Конкурентні переваги мають вигідно відрізняти підприємство від конкурентів, задовольняти потреби споживачів, забезпечувати підприємству довгострокову конкурентну позицію на ринку, бути гнучкими та адаптованими до змін сучасного бізнес-середовища.

Доведено, що засобом досягнення конкурентоспроможної позиції підприємства на ринку є розробка конкурентної стратегії, що базується на системі цінностей споживачів. Впровадження принципу клієнтоорієнтованості та створення споживчої цінності визначено головними складовими забезпечення стійких конкурентних переваг.

За сучасних умов нестабільного ринкового середовища аргументовано доцільність розробки адаптивних маркетингових стратегій, що дають змогу підприємствам реагувати на зміни ринкового середовища, мінімізувати ризики та втримати конкурентні позиції. Наголошено на необхідності забезпечення системного підходу до формування стратегій окремих елементів комплексу маркетингу. Виділено напрями адаптивного маркетингового управління.

Узагальнено сучасні маркетингові технології, які можуть застосовувати підприємства 3 метою розширення цільової аудиторії, збільшення обсягів продаж та зміцнення своїх позицій на ринку. Їх особливостями є орієнтація на стратегічні цілі розвитку, інтегрованість із загальною системою управління підприємством, комплексність, безперервність та динамізм реалізації. Результатом ефективного 
використання цих технологій є успішна діяльність підприємств на ринку, досягнення маркетингових та управлінських цілей.

Ключові слова: маркетингове управління підприємством, маркетингові технології, ринкове середовище, конкурентні переваги, клієнтоорієнтованість, споживча иінність, конкурентоспроможність, маркетингова конкурентна стратегія.

\title{
MARKETING TECHNOLOGIES OF FORMATION OF COMPETITIVE ADVANTAGES OF ENTERPRISES
}

\author{
Lutsk National Technical University
}

The article considers the use of marketing technologies in order to form a competitive advantage. The research of foreign and domestic scientists concerning the sources of competitive advantages is systematized. The requirements to be met by competitive advantages are generalized and a systematized list of characteristics through which the essence of competitive advantages is revealed is given. Competitive advantages should favorably distinguish the company from competitors, meet the needs of consumers, provide the company with a long-term competitive position in the market, be flexible and adapted to changes in today's business environment.

It is proved that the means of achieving a competitive position of the enterprise in the market is the development of a competitive strategy based on the system of consumer values. The introduction of the principle of customer orientation and the creation of consumer value are identified as the main components of ensuring sustainable competitive advantages.

In the current conditions of unstable market environment, the expediency of developing adaptive marketing strategies that allow companies to respond to changes in the market environment, minimize risks and maintain a competitive position is argued. The need to provide a systematic approach to the formation of strategies of individual elements of the marketing complex is emphasized. The directions of adaptive marketing management are allocated.

Modern marketing technologies that can be used by enterprises in order to expand the target audience, increase sales and strengthen their market position are summarized. Their features are the focus on strategic development goals, integration with the overall management system of the enterprise, complexity, continuity and dynamism of implementation. The result of effective use of these technologies is the successful operation of enterprises in the market, the achievement of marketing and management goals.

Key words: enterprise marketing management, marketing technologies, market environment, competitive advantages, customer orientation, consumer value, competitiveness, marketing competitive strategy.

Постановка проблеми у загальному вигляді i iï зв'язок 3 важливими науковими та практичними завданнями. Одним із найважливіших завдань сучасних підприємств $\epsilon$ їх здатність адаптуватися до умов змінного ринкового середовища та досягнення стійких конкурентних переваг. Застосування маркетингових технологій в управлінні конкурентними перевагами дозволяє розширити можливості впливу підприємства на їх формування. Конкурентні переваги відображають сильні сторони підприємства і $є$ дуже важливими для цільового ринку. Тому питання використання маркетингових клієнторієнтованих технологій для забезпечення стратегічної ринкової позиції і конкурентоспроможності підприємств залишаються актуальними.

Аналіз останніх досліджень, у яких започатковано вирішення проблеми. Відповідно до сучасних підходів маркетинг $є$ однією 3 найважливіших функцій підприємства і забезпечує взаємодію підприємства і ринку. Зарубіжні і вітчизняні науковці, зокрема, Ф. Котлер, К. Келлер, М. Портер, Л. Балабанова, А. Войчак, С. Гаркавенко, С. Ілляшенко, С. Ковальчук, С. Крикавський, А. Павленко, П. Перерва, А. Старостіна, Н. Чухрай та багато інших учених створили теоретичну базу системного підходу до маркетингу. Проте, питання використання маркетингових технологій у формуванні конкурентних переваг підприємств потребують подальшого вивчення, особливо в контексті нестабільного ринкового середовища.

Цілі статті. Метою дослідження $є$ узагальнення підходів до формування конкурентних переваг та визначення ролі сучасних маркетингових технологій у забезпеченні стійких конкурентних позицій підприємств. 


\section{Виклад основного матеріалу дослідження 3 повним обгрунтуванням отриманих наукових результатів.}

Сучасні економічні умови функціонування вітчизняних підприємств характеризуються загостренням конкуренції, високими споживчими очікуваннями та стрімким розвитком інтернет-технологій. Тому, як зазначає Москаленко О. Д., «виробники змушенні шукати більш ефективні способи обслуговування та використовувати різноманітні маркетингові методи для утримання своїх конкурентних позицій» [1].

Незважаючи на значні напрацювання в сфері маркетингового управління діяльністю підприємств, дослідники відзначають також і певні проблеми ефективного використання маркетингових технологій 3 метою отримання конкурентних переваг: недостатня зосередженість на ринку та зорієнтованість на споживачів, неналежне управління відносинами із зацікавленими сторонами, невміння знаходити нові можливості та скористатись технологічними досягненнями, недосконалий процес маркетингового планування тощо [2].

У ситуації, коли традиційні маркетингові підходи неспроможні забезпечити успіх підприємств, Ф. Котлер пропонує їх замінити на сучасні клієнтоорієнтовані технології та фокусуватись виключно на цінностях, що існують протягом усього життя споживачів [3].

Встановлення і підтримка довгострокових відносин зі споживачами здійснюється за допомогою впровадження принципу клієнтоорієнтованості та створення споживчої цінності [1]. Найсильнішу конкурентну позицію на ринку буде мати підприємство, що створить найкращу цінність для більшості споживачів. А для цього необхідно не лише вивчати наявний попит, та його прогнозувати для відвоювання певної частки ринку в умовах загострення конкурентної боротьби.

Як констатують автори публікації [4], «зміни, що відбулися, змушують товаровиробників здійснювати пошук адекватних ситуації ефективних маркетингових інструментів, що дозволить виокремитися серед конкурентів, сформувати лояльність споживача та зайняти вигідну позицію на ринку».

Вищезазначене зумовлює необхідність пошуку шляхів формування конкурентних переваг підприємства.

Ж.-Ж. Ламбен [5] виділив три групи факторів формування конкурентних переваг підприємства:

1) якість продукції (відмінні якості товару, які мають підвищену цінність для споживача);

2) витрати виробництва (переваги підприємства в питаннях контролю над рівнем цін і витрат, адміністрування й управління товаром);

3) ключові компетенції (особливі навики або технології, які створюють унікальну цінність для споживача).

Тобто, конкурентна перевага за Ж.-Ж. Ламбеном - це характеристики і властивості товару, що створюють для підприємства певний пріоритет над конкурентами.

Крім того, науковець всі конкурентні переваги поділяє на внутрішні (виробничі, технологічні, організаційні, управлінські тощо) та зовнішні (загальноекономічний стан ринків, політика уряду, рівень інтеграції процесу виробництва і реалізації продукції тощо). Внутрішні конкурентні переваги засновані на функціональних сферах діяльності підприємства і характеризують цінності для виробника. Зовнішні конкурентні переваги характеризують ринкову перевагу підприємства у задоволенні потреб споживача.

На думку Ф. Котлера [6] джерелом конкурентних переваг підприємства $\epsilon$, насамперед, його відмінні особливості. М. Портер [7] до основних джерел стійкої конкурентної переваги відносить: унікальну конкурентну позицію підприємства; 
ретельно підібрану систему видів діяльності; ставлення до конкурентів; визначення ключових факторів успіху.

Сучасні дослідники [8] узагальнивши підходи різних учених, встановили, що джерелами формування конкурентних переваг підприємства можуть бути: кваліфікована робоча сила, сприятливі умови виробництва, створення нових видів продукції чи інших інновацій, суттєве зниження собівартості продукції, iї висока якість, унікальність та оптимальний асортимент, що відповідає потребам споживачів, регулювання цін підприємством, високий рівень соціальної відповідальності.

Більшість науковців розглядає в якості бази конкурентних переваг підприємства саме внутрішні конкурентні переваги, які відображають потенціал досягнення підприємством своїх конкурентних позицій. В свої чергу, зовнішні конкурентні переваги, з одного боку, орієнтують підприємство на розвиток та використання тих чи інших внутрішніх переваг, а з іншого - забезпечують йому стійкі конкурентні позиції, оскільки орієнтують на цілеспрямоване задоволення потреб конкретної групи споживачів [8].

А. Ніколаєва конкурентні переваги підприємства пропонує розглядати як «сукупність внутрішніх і зовнішніх можливостей, компетенцій та динамічної спроможності, що забезпечують домінування підприємства 3 певною часткою відповідного релевантного ринку над конкурентами й унеможливлюють перерозподіл ринку на користь інших підприємств» [9].

Як зазначає Т. Харчук [10], для того, щоб перевага приносила перемогу у боротьбі iз конкурентами, вона має відповідати наступним вимогам: забезпечувати підприємству вигідне ринкове положення порівняно з конкурентами; бути націленою на специфічні запити клієнта, що дозволить принести користь цільовій групі споживачів; спиратися на специфічні, оригінальні здатності й ресурси підприємства, які не піддаються імітації 3 боку конкурентів; мати інноваційний характер для визначення напрямів і встановлення пріоритетності заходів щодо управління підприємством. Автор наводить систематизований перелік характеристик, через які виявляється сутність конкурентних переваг:

- здатність підприємства ефективно розподіляти ресурси, досягаючи більш стійкого і тривалого положення на ринку ніж конкуренти;

- сукупність характеристик ресурсів та цінностей, якими володіє підприємство і які забезпечують йому перевагу над конкурентами;

- результат більш ефективного за конкурентів управління процесами формування $\mathrm{i}$ розвитку якісних і кількісних властивостей продукту, що мають цінність для покупця.

Засобом використання внутрішнього потенціалу підприємства для досягнення конкурентоспроможної позиції на ринку $є$ формування конкурентної стратегії. О. Москаленко визначає конкурентну стратегію як «комплекс дій, направлених на формування цінності для суб'єктів ринку та суспільства в цілому, як джерела стійких конкурентних переваг. Підприємство, яке буде найкращим чином задовольняти потреби суб'єктів рику та надавати їм товар, який відповідає їх системі цінностей, зможе зайняти стійку конкурентоспроможну позицію на ринку, де пропозиція перевищує попит» [1].

Визначення конкурентної стратегії підприємства та його конкурентної позиції буде залежати, насамперед, від рівня відповідності діяльності та товарів виробників системі цінностей споживачів.

Маркетингова конкурентна стратегія є необхідним елементом системи управління підприємством. Маркетингові технології ринкового аналізу (насамперед, потреб ринку) дозволяють підприємству розробити ефективні стратегії, що спрямовані на конкретні сегменти споживачів. Це, в свою чергу, надає підприємству певні конкурентні переваги. Л. Кустріч [11] розробку маркетингової конкурентної стратегії розглядає як 
взаємопов'язану сукупність управлінських рішень щодо створення i використання конкурентних переваг підприємства i до складових системи маркетингових конкурентних стратегій відносить: стратегії формування конкурентних переваг, стратегії забезпечення конкурентоспроможності підприємства та стратегії конкурентної поведінки підприємства.

При цьому дослідник наголошує на необхідності забезпечення системного підходу до формування стратегій окремих елементів комплексу маркетингу, узгодження їх цілей i загальної спрямованості: «ефективне позиціювання та розробка відповідного комплексу маркетингу для цільового ринку є джерелом стійкої конкурентної переваги підприємства на ринку» [11].

За сучасних умов нестабільного ринкового середовища при формуванні маркетингової конкурентної стратегії підприємства необхідно надати ій саме тих характеристик, які будуть сприяти адаптації підприємства до існуючої ситуації. Значна кількість наукових праць [12-15] присвячена саме розробці адаптивних маркетингових стратегій, які дають змогу «реагувати на зміни ринкового середовища, оперативно i ефективно відновлювати порушену рівновагу підприємства, швидко зорієнтуватися і віднайти в умовах економічного спаду те рішення, яке допоможе підприємству утримати конкурентні позиції, мінімізувати ризики, надати ринку затребуваний продукт, тим самим задовольнивши споживацький попит» [15].

Все більше підприємств визнають розробку адаптивної маркетингової стратегії як можливість підвищити свою конкурентоспроможність на ринку особливо із врахуванням нових умов діяльності під впливом пандемії COVID-19.

I. Бойчук [12] виділяє такі основні напрями удосконалення маркетингового управління підприємствами за критичних умов: 1) тісна співпраця 3 існуючими клієнтами, яка, на думку автора, виходить за межі формальних угод, ведення переговорів i налагодження контактів в сфері здійснення закупівлі (база лояльних клієнтів перетворюються на головний актив; споживачам потрібно допомогти у вирішенні їхніх проблем, інвестуючи у зміцнення відносин з ними); 2) ретельне відстежування ситуації на ринку та оперативне реагування на зміни, пов'язані з виникненням нестандартних запитів у клієнтів, які можна задовольнити, якщо на них вчасно і вміло реагувати; 3) активна робота 3 «гарячим попитом» (необхідність виживання змушує підприємства «чіплятися» за кожного клієнта і здійснювати максимально ефективно всі продажі); 4) переосмислення ринкових пропозицій (зворотний зв'язок 3 клієнтами шляхом використання специфічних методів і прийомів ефективної комунікації може дати якісні ідеї щодо вдосконалення маркетингової діяльності та актуалізації ринкової пропозиції); 5) перегляд бізнес-процесів 3 точки зору управління цінностями для споживачів (необхідно позбутися процесів, які не несуть цінності, а ресурси направити на ті складові, які їх примножать, наприклад, створення комфортного середовища взаємодії для споживача).

Адаптивне управління маркетингом в процесі вибору активних комунікацій передбачає поєднання внутрішніх i зовнішніх комунікаційних складових на підприємстві, які враховують реальні цінності та очікування споживачів.

Крім того, як зазначають В. Готра та Ю. Філін, «адаптивна маркетингова стратегія повинна забезпечити наявність ефективного і перспективного товарного портфеля підприємства, вибрати для підприємства цільові ринки і сегменти, найефективніші канали збуту, сприяти вибору оптимальних методів призначення цін на продукцію підприємства, стимулювати збільшення кількості потенційних споживачів товарів компанії, сформувати позитивний імідж компанії в свідомості представників цільових аудиторій, визначити інтенсивність освоєння ринків» [13].

Нові маркетингові підходи в управлінні діяльністю підприємств за умов мінливого 
та нестабільного економічного середовища дозволяють створити умови для отримання конкурентних переваг як на національному, так і на зарубіжних ринках. Узагальнення досліджень $[2 ; 16 ; 17 ; 18]$ дає змогу виділити сучасні маркетингові технології, які варто застосовувати підприємствам 3 метою завоювання стійких позицій на ринку та ефективного функціонування.

Це, насамперед: 1) CRM-системи управління відносинами з клієнтами (спрямовані на вивчення ринку і потреб споживачів, управління взаємодією 3 наявними та потенційними клієнтами); 2) вірусний маркетинг (технологія, що дозволяє в найкоротші терміни поширити інформацію про компанію, продукт чи послугу; стрімке поширення соціальних мереж сприяє розвитку вірусного маркетингу та підвищує його ефективність); 3) маркетингові Інтернет-технології (сприяють розширенню можливостей підприємства у просуванні товарів і послуг та більш ефективному задоволенню потреб споживачів за допомогою інформаційних комунікаційних технологій); 4) інтегровані маркетингові комунікації (забезпечують ефективну взаємодію з клієнтами за рахунок інтеграції всіх комунікативних інструментів); 5) брендинг (передбачає створення тривалої прихильності до товару); 6) крос-маркетинг (взаємовигідне партнерство двох і більше підприємств, що передбачає спільне проведення маркетингових програм щодо просування супутніх товарів і послуг). Використання цих технологій сприятиме досягненню підприємствами своїх маркетингових та управлінських цілей.

Висновки. За сучасних умов маркетингові технології набувають все більшого значення в управлінні діяльністю підприємств в цілому та у формуванні конкурентних переваг, зокрема. Вони спрямовані на успішну діяльність підприємств на ринку, зростання рівня конкурентоспроможності та сприяють досягненню маркетингових цілей шляхом розробки маркетингових конкурентних стратегій. Практичне використання маркетингових технологій дасть змогу підприємствам обирати найбільш ефективні у конкретній ринковій ситуації маркетингові заходи, обгрунтовувати вибір маркетингових інструментів та оптимізувати маркетингові процеси.

\section{Список бібліографічного опису:}

1. Москаленко О. Д., Зозульов О. В. Маркетинг у формуванні конкурентних позицій на ринку промислових послуг на прикладі ринку системної інтеграції України. Актуальні проблеми економіки та управління : збірник наукових праць. 2020. Вип. 14. URL : https://ela.kpi.ua/bitstream/123456789/36969/1/APEU-2020-14_Moskalenko_Zozulov.pdf

2. Кузьмак О. I., Шайдюк А. С. Сучасні маркетингові технології як інструмент ефективного управління підприємствами в умовах глобалізації. Наукові записки Національного університету «Острозька академія». Серія «Економіка» : науковий журнал. Острог : Вид-во НаУОА, вересень 2020. № 19(47). С. 57-63.

3. Котлер Ф., Картаджайя Х., Сетиаван А. Маркетинг 3.0: от продуктов к потребителям и далее - к человеческой душе; пер. с англ. А. Ю. Заякина. Москва : Альпина Бизнес Букс, 2012. 227 с.

4. Боліла С. Ю., Кириченко Н. В., Осадчук І. В. Клієнторієнтовані технології формування конкурентних переваг м'ясопереробного підприємства на локальному ринку. Агросвіт. 2020. № 10. С. 78-86.

5. Ламбен Ж.-Ж. Менеджмент, ориентированный на рынок. Санкт-Петербург : Питер, 2007. 800 с.

6. Котлер Ф. Маркетинг менеджмент. Экспресс-курс; пер. с англ. под ред. С. Г. Божук. Санкт-Петербург : Питер, 2005. $464 \mathrm{c}$.

7. Портер М. Конкуренция; пер. с англ. Москва : Вильямс, 2005. 608 с.

8. Цьвок Д. Р., Яворська Н. П. Формування конкурентних переваг підприємства. Проблеми системного підходу в економіці. 2017. Вип. 5. С. 141-147.

9. Ніколаєва А. М. Формування стратегії досягнення конкурентних переваг підприємств м'ясної промисловості : дис. канд. наук: 08.00.04. Луцьк: ЛНТУ, 2010. 218 с.

10. Харчук Т. В. Підходи до визначення конкурентних переваг підприємства. Экономика и управление. 2011. № 6. C. 68-71.

11. Кустріч Л. О. Маркетингова конкурентна стратегія як необхідний елемент системи управління підприємством. Науковий вісник Херсонського державного університету. Сер. : Економічні науки. 2019. Вип. 33. С. 112-116.

12. Бойчук I. В. Адаптація управління маркетингом до умов пандемії COVID-19. Вісник Хмельницького націонал. університету. Економічні науки. Хмельницький: ХНУ, 2020. № 5. С. 38-41.

13. Готра В. В., Філін Ю. І. Розробка адаптивної стратегії маркетингу. Актуальні проблеми інноваційного розвитку кластерного підприємництва в Україні. 2017. С. 163-169.

14. Корінєв В. Л., Мартиненко Д. О. Стратегічне планування маркетингу як складова адаптивного управління підприємством. Держава та регіони. 2014. № 3 (78). С. 71-74. 
15. Соковніна Д. М. Адаптивна маркетингова стратегія підприємства: методика формування та реалізація. Економіка та держава. 2020. № 10. С. 89-92.

16. Ковінько О. М., Пасічник Т. Г. Особливості сучасних маркетингових технологій в управлінні підприємством. Молодий вчений. 2017. № 12. С. 647-650.

17. Марусей Т. В. Впровадження CRM-систем у маркетингову діяльність підприємства. Економіка та держава. 2016. № 6. C. 87-89.

18. Рзаєв Г. І. Дубік І. Г. Маркетингові технології : сутність та мета використання. Вісник Хмельницького національного університету. Економічні науки. 2019. № 5. С. 188-190.

\section{References:}

1. Moskalenko O. D., Zozulov O. V. (2020) Marketynh u formuvanni konkurentnykh pozytsii na rynku promyslovykh posluh na prykladi rynku systemnoi intehratsii Ukrainy. [Marketing in the formation of competitive positions in the market of industrial services on the example of the market of system integration of Ukraine]. Current problems of economics and management: a collection of scientific papers. 2020. Vip. 14. Recived from : https://ela.kpi.ua/bitstream/123456789/36969/1/APEU-202014_Moskalenko_Zozulov.pdf [in Ukrainian].

2. Kuzmak O. I., Shaidiuk A. S. (2020) Suchasni marketynhovi tekhnolohii yak instrument efektyvnoho upravlinnia pidpryiemstvamy $\mathrm{v}$ umovakh hlobalizatsii [Modern marketing technologies as a tool for effective management of enterprises in the context of globalization]. Scientific notes of the National University «Ostroh Academy». Series «Economics»: scientific journal. Ostrog: NaUOA Publishing House, no. 19 (47). pp. $57-63$ [in Ukrainian].

3. Kotler F., Kartadzhaiia Kh., Setyavan A. (2012) Marketynh 3.0: ot produktov k potrebyteliam y dalee - k chelovecheskoi dushe; per. s anhl. A. Yu. Zaiakyna [Marketing 3.0: from products to consumers and beyond - to the human soul]. Moscow: Alpina Business Books [in Russian].

4. Bolila S. Yu., Kyrychenko N. V., Osadchuk I. V. (2020) Kliientoriientovani tekhnolohii formuvannia konkurentnykh perevah miasopererobnoho pidpryiemstva na lokalnomu rynku [Client-oriented technologies of formation of competitive advantages of the meat-processing enterprise in the local market]. Agrosvit. no 10. pp. 78-86. [in Ukrainian].

5. Lamben Zh.-Zh. (2007) Menedzhment, oryentyrovannyi na rynok [Market-oriented management]. St. Petersburg: Peter [in Russian].

6. Kotler F. (2005) Marketynh menedzhment. Ekspress-kurs; per. s anhl. pod red. S. H. Bozhuk [Marketing Management. Express course]. St. Petersburg: Peter [in Russian].

7. Porter M. (2005) Konkurentsyia; per. s anhl. [Competition]. St. Petersburg: Peter [in Russian].

8. Tsvok D. R., Yavorska N. P. (2017) Formuvannia konkurentnykh perevah pidpryiemstva [Formation of competitive advantages of the enterprise]. Problems of system approach in economy. 2017. no. 5. pp. 141-147 [in Ukrainian].

9. Nikolaieva A. M. (2010) Formuvannia stratehii dosiahnennia konkurentnykh perevah pidpryiemstv miasnoi promyslovosti : dys. kand. nauk: 08.00 .04 [Formation of strategy of achievement of competitive advantages of the enterprises of the meat industry] Lutsk: LNTU [in Ukrainian].

10. Kharchuk T. V. (2011) Pidkhody do vyznachennia konkurentnykh perevah pidpryiemstva [Approaches to determining the competitive advantages of the enterprise] Economics and management. no. 6. pp. 68-71 [in Ukrainian].

11. Kustrich L. O. (2019) Marketynhova konkurentna stratehiia yak neobkhidnyi element systemy upravlinnia pidpryiemstvom [Marketing competitive strategy as a necessary element of enterprise management system] Scientific Bulletin of Kherson State University. Ser. : Economic sciences. No. 33. pp. 112-116. [in Ukrainian].

12. Boichuk I. V. (2020) Adaptatsiia upravlinnia marketynhom do umov pandemii COVID-19 [Adaptation of marketing management to the conditions of the COVID-19 pandemic]. Bulletin of Khmelnytsky National. university. Economic sciences. Khmelnytsky: KhNU, № 5. pp. 38-41. [in Ukrainian].

13. Hotra V. V., Filin Yu. I. (2017) Rozrobka adaptyvnoi stratehii marketynhu [Development of adaptive marketing strategy] Actual problems of innovative development of cluster entrepreneurship in Ukraine. pp. 163-169 [in Ukrainian].

14. Koriniev V. L., Martynenko D. O. (2014) Stratehichne planuvannia marketynhu yak skladova adaptyvnoho upravlinnia pidpryiemstvom [Strategic marketing planning as a component of adaptive enterprise management] State and regions. 2014. № 3 (78). pp. 71 -74 [in Ukrainian].

15. Sokovnina D. M. (2020) Adaptyvna marketynhova stratehiia pidpryiemstva: metodyka formuvannia ta realizatsiia [Adaptive marketing strategy of the enterprise: methods of formation and implementation]. Economy and state. 2020. № 10. pp. 89-92. [in Ukrainian].

16. Kovinko O. M., Pasichnyk T. H. (2017) Osoblyvosti suchasnykh marketynhovykh tekhnolohii v upravlinni pidpryiemstvom [Features of modern marketing technologies in enterprise management]. A young scientist. 2017. no 12. pp. 647-650. [in Ukrainian].

17. Marusei T. V. (2016) Vprovadzhennia CRM-system u marketynhovu diialnist pidpryiemstva [Implementation of CRMsystems in the marketing activities of the enterprise]. Economy and state. 2016. No 6. pp. 87-89. [in Ukrainian].

18. Rzaiev H. I. Dubik I. H. (2019) Marketynhovi tekhnolohii : sutnist ta meta vykorystannia [Marketing technologies: essence and purpose of use]. Bulletin of Khmelnytsky National University. Economic sciences. 2019. no 5. pp. 188-190 [in Ukrainian].

Дата подання публікації 10.07.2021p. 